Revue bibliographique pour le domaine irano-aryen

\title{
A Persian Perspective, Essays in memory of Heleen Sancisi-Weerdenburg. Leiden, 2003, XXI-361 p., ill. (Achaemenid History XIII).
}

\section{Rémy Boucharlat}

\section{(2) OpenEdition}

1 Journals

\section{Édition électronique}

URL : http://journals.openedition.org/abstractairanica/3324

ISSN : 1961-960X

\section{Éditeur :}

CNRS (UMR 7528 Mondes iraniens et indiens), Éditions de l'IFRI

\section{Édition imprimée}

Date de publication : 15 mai 2005

ISSN : 0240-8910

\section{Référence électronique}

Rémy Boucharlat, «A Persian Perspective, Essays in memory of Heleen Sancisi-Weerdenburg. Leiden, 2003, XXI-361 p., ill. (Achaemenid History XIII). », Abstracta Iranica [En ligne], Volume 26 | 2005, document 109, mis en ligne le 08 décembre 2005, consulté le 25 septembre 2020. URL : http:// journals.openedition.org/abstractairanica/3324

Ce document a été généré automatiquement le 25 septembre 2020.

Tous droits réservés 


\title{
A Persian Perspective, Essays in memory of Heleen Sancisi- Weerdenburg. Leiden, 2003, XXI-361 p., ill. (Achaemenid History XIII).
}

\author{
Rémy Boucharlat
}

1 Depuis l'arrêt volontaire des fameux et si utiles « Achaemenid Workshops », fondés en 1980 par H. Sancisi-Weerdenburg, la série des Achemenid History publie des monographies et des recueils d'articles. Cet ouvrage appartient à cette dernière catégorie et n'a pu accueillir tous ceux qui voulaient rendre hommage à $\mathrm{H}$. SancisiWeerdenburg (1944-2000), dont «l'initiative a donné une impulsion radicalement nouvelle aux recherches achéménides » (P. Briant).

2 Les quatorze contributions portent sur l'iconographie (Root (c.r. $\mathrm{n}^{\circ} 134$ )) et l'architecture de Persépolis et Pasargades (Seidl (c.r. $n^{\circ} 138$ ), Boucharlat (c.r. $\left.n^{\circ} 146\right)$ ), les textes élamites de Persépolis (Henkelman (c.r. $\left.n^{\circ} 107\right)$ ), la structure de l'empire (Jacobs, Wiesehöfer) et son impact dans les satrapies (Briant (c.r. $\left.n^{\circ} 86\right)$ ), GürtekinDemir (c.r. $\left.n^{\circ} 105\right)$, Kaptan (c.r. $\left.n^{\circ} 113\right)$, Stolper (c.r. $n^{\circ} 139$ ), les relations avec les Grecs (Brosius (c.r. $\left.n^{\circ} 90\right)$ ), des questions d'historiographie (Van der Spek (c.r. $n^{\circ} 141$ ), Kuhrt (c.r. $\left.n^{\circ} 115\right)$ ) et un voyageur à Persépolis (Gunter (c.r. $\left.n^{\circ} 104\right)$ ). Tous ces thèmes ont été abordés par H. Sancisi-Weerdenburg dans un ou plusieurs articles, mais d'autres encore, souvent provocants intellectuellement, ont fait d'elle une grande figure des études achéménides. Son œuvre scientifique personelle réalisée en moins de 25 ans est impressionnante (pp. 1-7). 
INDEX

Thèmes : 3.2.2. Pré-Achéménides et Achéménides

\section{AUTEURS}

RÉMY BOUCHARLAT

CNRS - Lyon 